\title{
STUDI POLA DAN DERAJAT KEMITRAAN PEMASARAN MANGGA ANTARA PETANI MANGGA DENGAN UD WULAN JAYA
}

\author{
Elly Rasmikayati ${ }^{1}$, Yudistira Haikal Arisyi ${ }^{1}$, Bobby Rachmat Saefudin ${ }^{2}$, Fitri \\ Awaliyah $^{3}$ \\ ${ }^{1}$ Fakultas Pertanian, Universitas Padjadjaran, Jatinangor, Sumedang, Indonesia \\ ${ }^{2}$ Fakultas Pertanian, Ma'soem University, Jatinangor, Sumedang, Indonesia \\ ${ }^{3}$ Fakultas Pertanian, Universitas Garut, Tarogong Kaler, Garut, Indonesia.
}

Email: e.rasmikayati@unpad.ac.id; wk.yudist@gmail.com; bobbyrachmat@masoemuniversity.ac.id; fitriawaliyah@uniga.ac.id

\begin{abstract}
ABSTRAK
Studi Pola Dan Derajat Kemitraan Pemasaran Mangga antara Petani Mangga dengan UD Wulan Jaya.Kemitraan mangga seyogyanyadapat meningkatkan kesejahteraan petani mangga, namun sering kali kesepakatan kemitraan antara petani dan perusahaan mitra yang tertuang dalam kontrak belum berfungsi dengan baik dalam pelaksanaannya. Penelitian ini bertujuan untuk mengetahui pola dan derajat kemitraan pemasaran mangga antara petani mangga dengan perusahaan mitra. Objek penelitian adalah hubungan kemitraan antara petani mangga dengan UD Wulan Jaya sebagai perusahaan mitra eksportir mangga di Kecamatan Singdangkasih, Kabupaten Majalengka, Provinsi Jawa Barat. Desain penelitian yang digunakan adalah penelitian kuantitatif dengan metode penelitian survey. Data dianalisis dengan menggunakan pedoman penetapan tingkat hubungan kemitraan usaha pertanian berdasarkan Keputusan Menteri Pertanian nomor 944/Kpts/OT.210/10/97 Tanggal 13 Oktober 1997. Hasil penelitian menunjukkan bahwa pola kemitraan yang diterapkan oleh UD Wulan Jaya dengan petani mitra adalah pola KOA dengan derajat kemitraan sebesar 721 yang menyatakan bahwa kemitraan berada pada tingkat Madya.
\end{abstract}

Kata kunci : Agribisnis mangga, Derajat kemitraan, Eksportir mangga, Kemitraan mangga, Pola kemitraan.

\begin{abstract}
Study of Pattern and Levelof Mango Marketing PartnershipBetween Mango Farmers and UD Wulan Jaya.Mango partnerships should improve the welfare of mango farmers, but often partnership agreements between farmers and partner companies as stipulated in the contract do not working properly in their implementation. This study aims to determine the pattern and level of mango marketing partnershipbetween mango farmers andpartner company. The object of research is the partnership relationship between mango farmers and UD Wulan Jaya as a mango exporter partner company in Singdangkasih District, Majalengka Regency, West Java Province. The research design used is quantitative study with survey research methods. Data were analyzed using guidelines for determining the level of partnership of agricultural business partnerships based on Minister of Agriculture Decree number 944/Kpts/OT.210/10/97 dated October 13, 1997. The results showed that the partnership pattern adopted by UD Wulan Jaya tothe farmers was the KOA pattern with a partnership level of 721 which states that the partnership is at the Intermediate level.
\end{abstract}

Key words : Partnership pattern, Degree of partnership, Mango partnership, Mango agribusiness, Mango Exporter.

\section{PENDAHULUAN}

Produksi mangga pada tahun 2017 mencapai 22,738,434 kuintal, perkembangan yang bisa dikatakan cukup signifikan apabila dibandingkan dengan tahun 2016 dengan jumlah produksi 
sebanyak 18,145,397 kuintal. Hal tersebut menempatkan Indonesia sebagai negara produsen mangga terbesar ke lima di dunia setelah India, China, Thailand dan Meksiko (World Atlas, 2018). Per Agustus, volume ekspor mangga tumbuh menjadi 939 ton dengan harga jual US\$994.3 per ton. Pertumbuhan dan harga jual ini lebih besar daripada tahun 2016 dengan volume ekspor sebesar 473 ton dan dijual di level US\$638.1 per ton. (Ditjen Hortikultura, 2018).

Menurut Etzioni (1985), penataan struktur agribisnis dapat dilakukan bila adanya pengadaan organisasi yang berperan dalam melancarkan komunikasi antar subsistem yang menyediakan barang dan subsistem yang memerlukan barang. Sistem agribisnis dapat dikatakan berhasil apabila adanya upaya dalam membangun suatu kemitraan antar pelaku agribisnis. Berbagai program kemitraan telah dikembangkan pada komoditas pertanian, namun sebagian besar belum menunjukan kinerja optimal termasuk pada komoditas hortikultura yang dimana mangga merupakan salah satunya. Pada program kemitraan seringkali adanya kegagalan karena kemitraan yang dikembangkan berujung pada pelanggaran kesepakatan sehingga cenderung memberikan manfaat kepada salah satu pihak saja (Yuzja, 1998 dalam Darwis dkk., 2016).

Kemitraan berupa contract farming sudah menjadi sistem yang sudah lama diterapkan oleh kelima negara tersebut dan bentuk kesepakatannya hampir beragam antara memang masih menggunakan kesepakatan secara informal dengan verbal ataupun verbal semi tertulis.Kelembagaan berpengaruh secara nyata terhadap peningkatan dinamika agribisnis petani, salah satu unsur yang termasuk di dalamnya adalah mitra bisnis yang berperan dalam memberikan akses permodalan untuk keberlanjutan usahatani mangga (Rasmikayati dan Saefudin, 2018). Adapun manfaat pengembangan kelembagaan kemitraan usaha dalam rangka meningkatkan daya saing komoditas adalah tercapainya skala ekonomi usahatani maupun dalam pengangkutan, adanya transfer teknologi dan informasi dari perusahaan kepada masyarakat petani, lalu adanya peningkatan akses terhadap pasar dan adanya keterpaduan dalam pengambilan keputusan yang membuat usahatani sejalan dengan dinamika permintaan pasar (Saptana dan Indraningsih, 2006).

$$
\text { Petani produk hortikultura }
$$

khususnya petani mangga, seharusnya mendapatkan dampak peningkatan pendapatan, dimana ketika kemitraan telah dilakukan, kegiatan pertanian baik off-farm dan on-farm akan menjadi lebih efektif dan efisien dengan bantuan mitra. Hal ini merupakan keuntungan tersendiri bagi petani terlebih lagi apabila petani bermitra dengan perusahaan yang lebih menjamin. Hanya saja, hubungan kemitraan menuntut petani untuk menepati dan memenuhi perjanjian atau kontrak yang sudah disepakati bersama dengan mitra.

Tabel 1. Rataan Marjin Pemasaran Menurut Kelembagaan Pemasaran dan Persentase Bagian Harga yang Diterima Petani Mangga terhadap Kelembagaan Pemasaran (Farmer Share) di Kabupaten Majalengka Tahun 2005.

\begin{tabular}{lccc}
\hline \multicolumn{1}{c}{ Kelembagaan Pemasaran } & $\begin{array}{c}\text { Harga Jual } \\
(\mathbf{R} \mathbf{K} / \mathbf{K g})\end{array}$ & $\begin{array}{c}\text { Marjin Pemasaran } \\
(\mathbf{R p} / \mathbf{K g})\end{array}$ & $\begin{array}{c}\text { Farmer Share } \\
(\boldsymbol{\%})\end{array}$ \\
\hline 1. Petani & 2.623 & - & - \\
2. Pedagang Pengumpul & 2.873 & 185 & 91,3 \\
3. Pedagang Pengepul/Agen & 4.200 & 1.177 & 62,45
\end{tabular}




\begin{tabular}{lccc}
\hline \multicolumn{1}{c}{ Kelembagaan Pemasaran } & $\begin{array}{c}\text { Harga Jual } \\
(\mathbf{R p} / \mathbf{K g})\end{array}$ & $\begin{array}{c}\text { Marjin Pemasaran } \\
(\mathbf{R p} / \mathbf{K g})\end{array}$ & $\begin{array}{c}\text { Farmer Share } \\
(\boldsymbol{\%})\end{array}$ \\
\hline 4. Pedagang Pasar Induk & 4.904 & 662 & 53,49 \\
5. Supplier & 6.142 & 1.445 & 42,71 \\
6. Pasar Tradisional & 6.500 & 860 & 40,35 \\
7. Kios Buah & 6.900 & 1.400 & 38,01 \\
8. Pasar Modern/Supermarket & 10.000 & 1.100 & 26,23 \\
\hline
\end{tabular}

Sumber:Agustian et al (2005) dalam Anugrah (2009)

Pada kasus kemitraan pemasaran di kabupaten Majalengka, perbandingan farmer share petani pada setiap hubungan kerjasama dengan kelembagaan pemasaran pada salah satu rantai yang ada di Kabupaten Majalengka, penerimaan akhir petani hanya sebesar $26.33 \%$ dari harga akhir konsumen (Tabel 1). Hal ini menunjukkan bahwa kurang efisiennya rantai pemasaran yang ada sehingga ada peningkatan harga yang begitu signifikan dari harga jual dari petani. Perlu adanya hubungan kemitraan yang dapat menyediakan rantai pemasaran yang efisien sehingga penerimaan petani dapat lebih besar (Sari dkk., 2019). Mengacu kepada Rasmikayati et al., (2019) bahwa faktor kelembagaan dalam subsistem pemasaran agribisnis yang merupakan faktor yang berpengaruh signifikanmeningkatkan perilaku agribisnis petani mangga.

Tidak semua hubungan kemitraan memberikan bantuan secara kontinu dan menyisakan beberapa kegiatan yang sifatnya membebani petani untuk ditanggung oleh petani itu sendiri baik secara fisik maupun biaya. Kinerja kelembagaan kemitraan usaha pada buah tropika baik yang dilakukan melalui pola dagang umum maupun pertanian kontrak (contract farming) belum sepenuhnya efisen (Saptana dkk, 2007).

Melalui kemitraan diharapkan adanya pembinaan terkait usaha tani, budidaya tanaman, bantuan penyaluran barang dalam sistem pemasaran juga pemberian modal seperti bibit pohon mangga atau berupa alat penunjang lainnya secara berkelanjutan (Rachmah dkk, 2019). Sehingga dapat mencukupi kebutuhan petani agar produksi mangga tetap stabil dan memberikan dampak yang signifikan terhadap pendapatan yang diterima oleh petani yang tentunya menjadi lebih besar dan mencukupi.

Hanya saja, pada kenyataannya seluruh peran tersebut belum bisa dimaksimalkan baik oleh pihak perusahaan maupun pihak petani. Tidak semua petani mangga dapat bergabung menjadi mitra dan sering keluar masuknya petani dari keanggotaan kemitraan dikarenakan ketidakpuasan yang dialami dari sisi pemberian informasi melalui pembinaan dan permodalan yang tidak berkelanjutan, juga peran penyalur dalam sistem pemasaran yang memberikan pendapatan yang dirasa masih kurang cukup, sehingga petani menjual hasil panennya kepada pihak lain untuk mendapatkan tambahan pendapatan yang sekaligus merupakan sebuah pelanggaran aturan kemitraan yang telah dilaksanakannya.Oleh karena itu, maka penelitian ini bertujuan untuk mengetahui pola dan derajat kemitraan pemasaran mangga antara petani mangga dengan perusahaan mitra.

\section{METODA PENELITIAN}

\subsection{Objek dan Tempat Penelitian}

Objek yang menjadi bahan penelitian adalah pendapatan petani mangga dengan meninjau hubungan kemitraan antara petani mangga dengan 
UD Wulan Jaya sebagai perusahaan mitra eksportir mangga. Penelitian dilaksanakan di Kecamatan Singdangkasih, Kabupaten Majalengka, Provinsi Jawa Barat.

\subsection{Desain dan Metode Penelitian}

Dalam penelitian ini, desain penelitian yang digunakan adalah penelitian kuantitatif yang bertujuan menguji teori secara objektif dengan cara meneliti hubungan antar variabel di mana variabel tersebut harus dapat diukur, sehingga data numerik yang dihasilkan dapat dianalisis secara statistik (Cresswell,2009).

Metode penelitian yang digunakan adalah metode penelitian survei.Penelitian surveibertujuan untuk mengumpulkan informasi tentang orang atau populasi yang berjumlah besar dengan cara mewawancarai sebagian kecil dari populasi tersebut. Penentuan sampel penelitian dilakukan dengan menggunakan metode Probability Sampling karena semua anggota populasi memiliki kesempatan yang sama untuk menjadi responden. Populasi dalam penelitian ini adalah petani mangga di Sindangkasih, Kabupaten Majalengka yang bermitra aktif dengan UD Wulan Jaya dalam menjalankan usahatani mangga. Jumlah $N=100$ orang dan tingkat presisi yang ditetapkan adalah $10 \%$. Berdasarkan rumus slovin, jumlah sampel $(n)$ yang diperoleh adalah sebagai berikut:

$$
\mathrm{n}=\frac{60}{1+60(0,1)^{2}}=37.5=38 \text { Orang }
$$

\subsection{Definisi Variabel Penelitian}

1) Pola Kemitraan

Pola Kemitraan merupakan deskripsi kerjasama yang dilakukan petani dengan mitra yang dapat diukur dari aspek teknis setiap tahapan yang dilakukan, meliputi: a. Jumlah Bibit, yaitu banyaknya bibit pohon mangga yang disediakan.

b. Lahan, yaitu tanah terbuka; tanah garapan yang digunakan untuk budidaya pohon mangga.

c. Waktu Tanam, yaitu lamanya menanam pohon mangga yang direncanakan.

d. Bimbingan Teknis, yaitu penjelasan terkait pelaksanaan budidaya mangga sesuai prosedur tertentu.

e. Inovasi Teknologi, yaitu pembaruan sarana tertentu dalam melakukan produksi mangga.

f. Jumlah Panen, yaitu banyaknya buah mangga yang bisa dihasilkan.

g. Harga Panen, yaitu nilai dari jumlah buah mangga yang dihasilkan dalam bentuk uang.

h. Cara Pembayaran, yaitu sebuah sistem atau aturan dalam melakukan pembelian hasil panen.

i. Sortasi Buah, yaitu proses seleksi buah mangga sesuai dengan standar mutu.

j. Tujuan Distribusi, yaitu sasaran tertentu proses perpindahan tangan hasil panen.

k. Pelaku Kemitraan, yaitu phak-pihak yang terlibat dalam proses kerjasama.

2) Derajat Kemitraan

Derajat Kemitraan merupakan deskripsi tingkatan bentuk kerjasama yang terjalin antara pihak yang terlibat yang tentunya dapat diukur dari aspek manajerial dan aspek manfaat, hal-hal tersebut meliputi:

a. Perencanaan, merupakan deskripsi terkait proses perencanaan yang terjadi dan kelengkapan atributatribut perencanaan dalam kemitraan.

b. Pengorganisasian, merupakan deskripsi adanya spesifikasi dalam pembagian tugas dan bentuk kesepakatan/kontrak. 
c. Pelaksanaan dan Efektivitas Kerjasama, yaitu gambaran pelaksanaan kerjasama secara keseluruhan.

d. Manfaat Ekonomi, yaitu dampak baik bagi pelaku kemitraan dari segi pendapatan, harga, produktivitas dan risiko usaha.

e. Manfaat Teknis, yaitu dampak baik dari pelaksanaan kemitraan dari segi mutu produk dan penguasaan teknologi.

f. Manfaat Sosial, yaitu dampak baik dari pelaksanaan kemitraan dari segi keinginan kontinuitas kerjasamam dan pelestarian lingkungan.

\subsection{Teknik Analisis Data}

Pola kemitraan tersebut dianalisis dengan mengetahui hak dan kewajiban pelaku mitra. Sedangkan untuk menghitung keberhasilan pelaksanaan kemitraan yaitu dengan mengukur derajat kemitraan mitra. Untuk mengukur derajat kemitraan yaitu dengan menilai dari aspek yang dirinci dalam setiap indikator, dimana indikator-indikator yang berhubungan dengan kesepakatan dalam kemitraan. Indikator-indikator yang digunakan tersebut memiliki nilai tertentu yang telah disesuaikan dengan Keputusan Menteri Pertanian Nomor 944/Kpts/OT.210/10/97 Tanggal 13 Oktober 1997 mengenai pedoman penetapan tingkat hubungan kemitraan usaha pertanian (Pertanian, B. A. D., 1998). Secara lebih jelas, metode pengukuran derajat kemitraan dapat dilihat pada Tabel 2.Nilai faktor maksimum sebagai nilai acuan yang telah ditetapkan oleh Badan Agribisnis, Departemen Pertanian, 1998 sedangkan untuk aspek faktor yang dinilai masih bisa disesuaikan dengan kondisi di lapangan sesuai dengan kemitraan yang dijalankan.

Tabel 2. Pengukuran Derajat Kemitraan

\begin{tabular}{|c|c|c|c|}
\hline Aspek & Indikator & Faktor yang dinilai & $\begin{array}{l}\text { Nilai Faktor } \\
\text { Maksimum }\end{array}$ \\
\hline \multirow{6}{*}{$\begin{array}{l}\text { I. Proses } \\
\text { Manajemen }\end{array}$} & 1. Perencanaan & a. Perencanaan Kemitraan & 100 \\
\hline & & $\begin{array}{l}\text { b. Kelengkapan } \\
\text { Perencanaan }\end{array}$ & 50 \\
\hline & 2. Pengorganisasian & a. Bidang Khusus & 25 \\
\hline & & b. Kontrak Kerjasama & 125 \\
\hline & $\begin{array}{l}\text { 3. Pelaksanaan dan Efektivitas } \\
\text { Kerjasama }\end{array}$ & a. Pelaksanaan Kemitraan & 50 \\
\hline & & b. Efektivitas Kerjasama & 150 \\
\hline \multicolumn{3}{|c|}{ Jumlah Nilai Maksimum Aspek Proses Manajemen Kemitraan } & 500 \\
\hline \multirow{8}{*}{ II. Manfaat } & 1. Ekonomi & a. Pendapatan & 100 \\
\hline & & b. Harga & 100 \\
\hline & & c. Produktivitas & 50 \\
\hline & & d. Risiko Usaha & 50 \\
\hline & 2. Teknis & a. Mutu & 50 \\
\hline & & b. Penguasaan Teknologi & 50 \\
\hline & 3. Sosial & $\begin{array}{ll}\text { a. } & \text { Keinginan Kontinuitas } \\
& \text { Kerjasama }\end{array}$ & 50 \\
\hline & & b. Pelestarian Lingkungan & 50 \\
\hline \multicolumn{3}{|c|}{ Jumlah Nilai Maksimum Aspek Manfaat } & 500 \\
\hline \multicolumn{2}{|l|}{ Total } & & 1000 \\
\hline
\end{tabular}

Sumber: Keputusan Menteri Pertanian nomor 944/Kpts/OT.210/10/97 Tanggal 13 Oktober 1997 


\section{HASIL PENELITIAN DAN PEMBAHASAN}

\subsection{PolaKemitraan Petani dengan UD Wulan Jaya}

Hubungan kerjasama antara petani mitra dengan perusahaan yaitu di bidang pemasaran, budidaya dan penyuluhan.

\section{Kerjasama di bidang pemasaran}

Perusahaan membeli hasil panen dari petani mitra maupun non mitra dan petani wajib menjual kepada perusahaan dengan kriteria yang telah ditentukan perusahaan. Hasil panen mangga dari petani hampir semuanya masuk ke perusahaan untuk semua ukuran karena perusahaan menapung semua ukuran dan bentuk, terkecuali jika terkena busuk atau terkena penyakit. Namun yang membedakan adalah harga yang akan diterima petani karena ukurannnya pun bebeda.

Petani mendapatkan fasilitas transportasi pengangkutan mangga dari lahan petani ke perusahaan. Walaupun terbatas jumlahnya, untuk transportasi sebagian petani memang tidak mempermasalahkan dikarenakan lokasi lahan yang cukup dekat dengan perusahaan. Begitu juga untuk bantuan bibit dan peti sebagai fasilitas yang disediakan perusahaan untuk petani yang membutuhkan. Bibit yang dibagikan merupakan bibit yang berasal dari pemerintah sebagai bantuan yang dikelola langsung oleh UD Wulan Jaya. Sistem pembayaran yang diterima petani yaitu secara tunai. Hal demikian membuat petani percaya untuk selalu menjual hasil panennya kepada perusahaan.

\section{Kerjasama di bidang budidaya}

Kerjasama di bidang budidaya tidak terlalu banyak yang dilakukan. Pihak perusahaan berperan sebagai koordinator bantuan pemerintah yang diberikan setiap periodenya. Hal ini dikarenakan bantuan pemerintah tersalurkan langsung kepada pihak sub kelompok tani Wulan Jaya yang diketuai oleh Bapak Novi Kriswanto yang juga merupakan pimpinan perusahaan UD Wulan Jaya sehingga bantuan pemerintah dibagikan sesuai dengan proporsinya dengan memperhatikan luas lahan yang petani mitra kuasai. Perihal Teknik budidaya, perusahaan menyerahkan kepada masingmasing petani karena sudah dianggap berpengalaman. Namun perusahaan tetap mengadakan media tersendiri untuk para petani bertukar informasi terkait teknik budidaya yang dipantau langsung oleh pihak perusahaan. Hal tersebut dilakukan agar selalu adanya pengawasan dengan tujuan menjaga kualitas mangga agar tetap sesuai dengan kesepakatan dan tentunya sesuai permintaan pasar. Selain itu, tujuan utama lainnya adalah untuk ikut serta mensukseskan program bersama dalam mencapai rasa tanggung jawab untuk mengusahakan keberlanjutan budidaya.

3. Kerjasama di bidang penyuluhan mitra Kesuksesan petani terhadap tugas perusahaan dalam memberikan penyuluhan di lapangan yaitu tercermin dalam hasil produksi yang besar dengan kualitas baik dan tetap berlanjut untuk meneruskan kemitraan. Keberlanjutan kerjasama kemitraan secara tidak langsung dirasakan petani yaitu mendapatkan motivasi untuk menjalin hubungan yang baik secara personal maupun hubungan jual beli yang berakhir mencapai manfaat bersama.

Dengan demikian, pola kemitraan yang terbentuk antara petani mitra dengan perusahaan UD Wulan Jaya menurut keputusan menteri pertanian No 940/Kpts/Ot.210/10/1997 termasuk ke 
dalam pola kerjasama operasional agribisnis (KOA). Dalam hal ini petani menyediakan lahan, tenaga kerja, bahan baku (pupuk dan obat-obatan) dan permodalan sendiri, sedangkan perusahaan menjamin produk dengan melakukan sortasi dan grading juga pemilihan pasar tetap dengan harga jual yang menguntunkan baik untuk petani maupun perusahaan.

\subsection{Derajat Kemitraan Petani dengan UD Wulan Jaya}

Analisis derajat kemitraan ini untuk melihat hubungan tingkat kemitraan yang terjadi antara petani mitra dengan UD Wulan Jaya. Nilai tersebut sudah ditetapkan oleh Badan Agribisnis Departemen Pertanian yaitu menggunakan nilai maksimum dari setiap faktor yang dinilai. Penilaian dilakukan dengan menganalisis dua aspek yaitu aspek proses manajemen kemitraan dan aspek manfaat. Total nilai dari kedua aspek tersebut yaitu 1000. Hasil analisis derajat kemitraan antara petani mangga dengan UD Wulan Jaya tersaji pada Gambar 1.

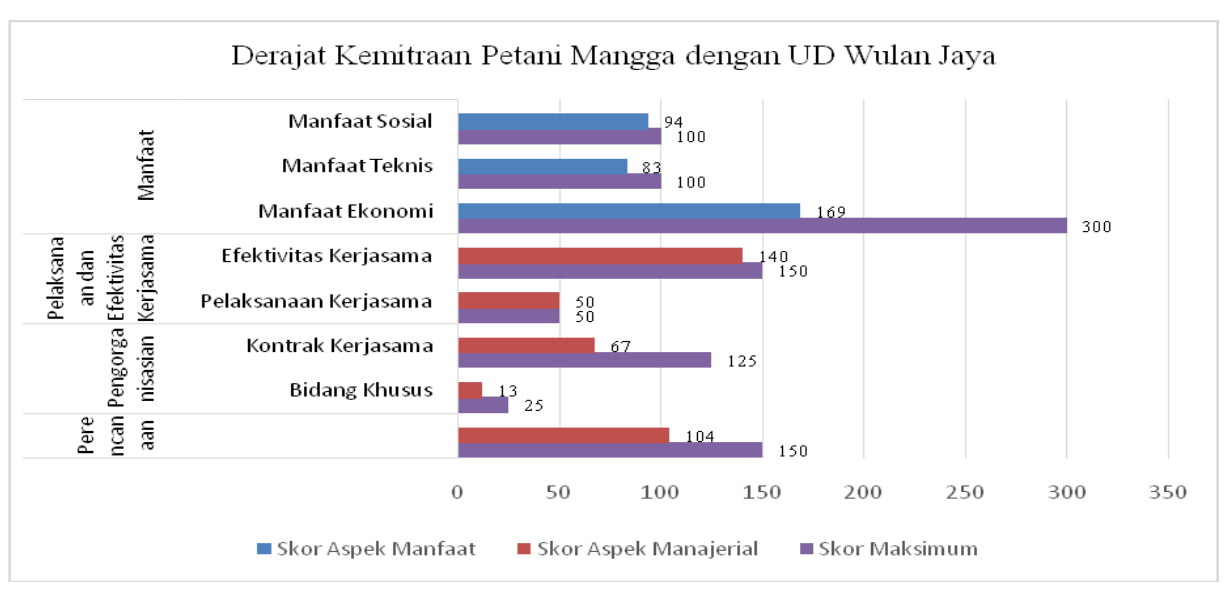

Gambar 1. Hasil Pengukuran Derajat KemitraanPetani Mangga dengan UD Wulan Jaya Sumber:Data Primer, diolah (2020)

Hasil analisis menunjukkan bahwa penilaian terhadap aspek proses manajemen kemitraan dan aspek manfaat kemitraan diperoleh nilai hasil akhir sebesar 721 (dari skor maksimum 1000)yang artinya kemitraan yang terjalin antara petani mitra dengan UD Wulan Jaya tergolong dalam tingkat kemitraan madya atau cukup baik (501-750). Nilai tersebut terdiri dari nilai aspek proses manajemen kemitraan sebesar 375 dan nilai aspek manfaat sebesar 346 .

Berikut ini akan dibahas mengenai hasil analisis derajat kemitraan secara rinci bagaimana sistem kemitraan yang terjadi antara petani mitra dengan UD Wulan Jaya serta akan terlihat bagaimana tingkat hubungan petani dengan perusahaan mulai dari perencanaan sampai kepada manfaat yang diperoleh pihak mitra.

\section{Aspek Proses Manajemen Kemitraan} Aspek proses manajemen kemitraan terdiri dari perencanaan, pengorganisasian dan pelaksanaan \& efektifitas kerjasama. Total nilai dari aspek ini yaitu 500 (50\%) dari jumlah keseluruhan. Nilai tersebut sudah menjadi standar ketetapan Badan Agribisnis Departemen Pertanian.

1) Perencanaan 
Perencanaan memberikan uraianuraian mengenai langkah-langkah kerjasama kemitraan yang akan dilaksanakan. Berdasarkan hasil penelitian responden petani mitra, bahwa sebanyak 39 orang petani mitra (100\%) menyatakan penyusunan rencana kemitraan hanya dilakukan oleh UD Wulan Jaya secara sepihak tanpa diketahui oleh petani. Petani mitra tidak ikut dalam mendiskusikan hal-hal mengenai perencanaan kemitraan, termasuk di dalamnya mengenai perumusan kontrak perjanjian kemitraan.

UD Wulan Jaya memang melakukan perencanaan kemitraan secara sepihak saja. Sebelumnya UD Wulan Jaya mengajak petani untuk melakukan perencanaan kemitraan, hanya saja respon dari petani tidaklah sesuai dengan ekspektasi perusahaan sehingga pada akhirnya petani mitra mempercayai dan menyerahkan segala halnya terkait kemitraan kepada perusahaan.

Hasil lainnya mengenai kelengkapan perencanaan, bahwa 18 orang petani mitra $(46,2 \%)$ menyatakan empat aspek kelengkapan perencanaan kemitraan yang terjadi pada UD Wulan Jaya meliputi aspek pemasaran, pembinaan teknologi, bimbingan, dan sarana produksi budidaya. Petani mitra lainnya yaitu 21 orang (54\%) menyatakan lingkup perencanaan meliputi lima aspek (pemasaran, pembinaan teknologi, bimbingan, saranan produksi budidaya, dan prasarana pertanian).

Hal tersebut menyimpulkan mayoritas petani menyatakan bahwa kemitraan dengan UD Wulan Jaya menyangkut aspek pemasaran, pembinaan tekhnologi, bimbingan, sarana produksi pertanian, dan prasarana pertanian. Aspek pemasaran petani diadakan dengan memberikan jaminan pasar, dimudahkan dalam sistem pengangkutan mangga dan diberikan informasi harga mangga per kilogramnya.
Sistem pengangkutan yaitu perusahaan meminjamkan kendaraan kepada petani untuk kemudian digunakan sebagai alat angkut mangga. Pembinaan dan bimbingan diberikan perusahaan dengan diadakannya rapat dalam rangka pembagian informasi terkait teknis budidaya hingga pemasaran (Amridha, 2020). Informasi tersebut berasal dari materi penyuluhan pemerintah juga materi perusahaan itu sendiri.

2) Pengorganisasian

Pengorganisasian terdiri dari bidang khusus yang menangani kemitraan dan pembahasan mengenai kontrak kerjasama. Kemitraan merupakan suatu bentuk kerjasama untuk mencapai win win solution. Pada dasarnya konsep bersama-sama tergabung dalam sebuah wadah organisasi ataupun yang lainnya. Dalam organisasi tersebut belajar untuk bekerjasama secara efektif supaya bisa memperoleh hasil dari yang telah dikerjakan.

Berdasarkan hasil penelitian, dihasilkan sebanyak 39 orang petani mitra $(100 \%)$ menyatakan bahwa tidak adanya bidang khusus dalam penanganan kemitraan yang dijalankan oleh UD Wulan Jaya dengan pihak yang bermitra. Semua hal yang dilakukan dalam kemitraan dilaksanakan oleh koordinator perusahaan yang sekaligus menangani kemitraan dengan sub kelompok tani Wulan Jaya.

Mengenai kontrak kerjasama, petani mitra sebanyak 39 orang $(100 \%)$ menyatakan bahwa kontrak dilaksanakan secara lisan. Hal tersebut dikarenakan petani mitra sudah mempercayai perusahaan atas segala ketentuanketentuan yang telah ditetapkan.

Petani merasa hubungan yang sudah terjalin dengan pihak perusahaan cukup untuk dijadikan modal untuk mempercayakan bagian hilir kepada perusahaan, sehingga tidak perlu adanya 
kontrak secara tertulis yang nantinya akan dirasa sangat memberatkan kedua pihak. Begitupun sebaliknya, pihak perusahaan merasa cukup dengan kontrak lisan dalam menjaga hubungan dengan petani mitra. Hanya saja perusahaan cukup terkendala dengan tidak adanya sanksi khusus yang tertulis apabila ada petani yang melanggar kesepakatan.

Idealnya kontrak kerjasama dibuat secara tertulis, sehingga pihak petani dan perusahaan sama-sama tertuntut atas hak dan kewajibannya secara jelas dan transparan. Kontrak kerjasama tertulis pun dapat memicu performa dan kontinuitas pasokan yang lebih baik (Eaton and Shepherd, 2001). Pihak perusahaan menyatakan bahwa kontrak kerjasama secara lisan mencakup bantuan sarana dan prasarana pertanian, penanganan bantuan pemerintah secara administratif, pembinaan dan penyuluhan budidaya mangga, jaminan harga dan pasar, sistem pembayaran dan standar kualitas mangga. Namun, masih saja adanya pelanggaran terhadap kontrak yang telah disepakati. Perusahaan pun tidak mempunyai sanksi tegas karena kekhawatiran petani tidak melanjutkan kerjasama.

\section{3) Pelaksanaan dan Efektivitas Kerjasama Pelaksanaan dan efektifitas kerjasama terdiri dari pelaksanaan kerjasama dan efektivitas kerjasama.} Berdasarkan hasil penelitian, bahwa 39 orang petani mitra $(100 \%)$ menyatakan bahwa pelaksanaan kemitraan sesuai dengan perjanjian dan dilakukan secara transparan. Hal tersebut, dapat disimpulkan bahwa pelaksanaan kemitraan dilakukan sesuai dengan perjanjian yang berada dalam kontrak dan dilakukan secara transparan. Maksud dari pelaksanaan yang dilakukan secara transparan yaitu pihak perusahaan siap menerima informasi dari petani ketika ada permasalahan di lapangan.
Perusahaan pun menetapkan cara seperti itu supaya hubungan antara petani, koordinator dengan perusahaan tetap mempunyai hubungan yang dekat dan terjaga.

Efektifitas kerjasama yaitu merupakan kemampuan untuk memilih sasaran yang tepat atau menjalankan pekerjaan dengan benar. Efektivitas kerjasama dapat dilihat dari kejelasan peranan, kontinuitas mangga, kualitas mangga, sistem pembayaran dan penentuan harga.

a) Kejelasan peranan

Sebanyak 39 responden (100\%) menyatakan bahwa petani maupun perusahaan mengetahui perannya masingmasing. Petani menyadari sebagai pihak yang menjalin mitra, begitupun dengan perusahaan. Peranan tersebut diketahui ketika perusahaan memberikan surat perjanjian kontrak kerjasama ataupun saat perusahaan memberikan penawaran kepada pihak yang akan bermitra. Peranan petani mitra yaitu melakukan kerjasama dalam penjualan komoditas mangga dengan kualitas yang telah ditentukan oleh perusahaan secara kontinu, sedangkan perusahaan sebagai pihak pembeli mangga dari petani mitra.

b) Kontinuitas Pasokan

Berdasarkan hasil penelitian, 39 petani mitra (100\%) menyatakan bahwa adanya kontinuitas komoditas mangga kepada UD Wulan Jaya, sesuai dengan kesepakatan dengan perusahaan perihal kontinuitas pasokan. Hanya saja, perusahaan menyatakan yang sebaliknya, bahwasannya pasokan komoditas mangga oleh beberapa petani mitra tidak kontinu bahkan perusahaan perlu melakukan pembelian kepada pihak pemasok di daerah lain untuk memenuhi permintaan konsumen. Walaupun begitu, sebagian petani lainnya memang dikatakan konsisten dalam penyediaan komoditas 
mangga tak hanya secara kuantitas, tetapi juga secara kualitas.

\section{c) Kualitas Pasokan}

Menurut analisis hasil penelitian, sebanyak 39 petani mitra (100\%) menyatakan bahwa mangga yang dipasok kepada perusahaan sesuai dengan standar mutu yang telah disepakati. Kriteria yang telah disepakati yaitu berwarna hijau keseluruhan, diameter sekitar tiga hingga empat $\mathrm{cm}$, serta bebas dari hama penyakit. Ketentuan ini berimplikasi kepada petani yang harus melakukan sortasi dengan baik terhadap hasil panennya sebelum diambil oleh perusahaan. Menurut petani mitra, bahwa sortasi tidak memberatkan karena beragamnya ukuran mangga tetap masuk ke perusahaan walaupun memperoleh harga berbeda.

\section{d) Sistem Pembayaran}

Berdasarkan kontrak kerjasama kemitraan, bahwa sistem pembayaran dilakukan secara tunai setelah mangga diterima perusahaan. Berdasarkan informasi yang diperoleh, sebanyak 39 petani mitra $(100 \%)$, menyatakan bahwa sistem pembayaran dilakukan sesuai dengan kontrak kerjasama.

\section{e) Cara Pembayaran}

Jual beli tentunya menyangkut dengan sistem pembayaran atas penjualan yang telah dilakukan. Sebanyak 39 orang (100\%) petani mitra, menyatakan bahwa pembayaran dilakukan secara tunai.

\section{f) Penentuan Harga}

Terkait penentuan harga sebanyak 33 petani mitra (85\%) menyatakan bahwa penentuan harga dilakukan oleh perusahaan mitra diketahui oleh koordinator atau pembina dan 6 petani mitra (15\%) lainnya menyatakan bahwa penentuan harga dilakukan oleh perusahaan mitra tanpa melibatkan kelompok petani mitra. Hal tersebut dapat disimpulkan bahwa penentuan harga dilakukan oleh perusahaan mitra diketahui oleh koordinator atau Pembina dengan memperhatikan juga harga mangga di pasar.

2. Aspek Manfaat

Berdasarkan Keputusan Menteri

Pertanian Nomor

944/Kpts/OT.210/10/1997 tentang

Pedoman Penetapan Tingkat Hubungan Kemitraan Usaha Pertanian, aspek manfaat kemitraan dapat dilihat dari tiga indikator yaitu manfaat ekonomi, manfaat teknis, dan manfaat sosial. Total nilai dari aspek manfaat ini yaitu $500(50 \%)$ dari total keseluruhan.

\section{1) Manfaat Ekonomi}

Indikator ekonomi ada beberapa faktor yang dinilai yaitu pendapatan, harga, produktivitas dan risiko usaha. Jumlah nilai dari aspek ekonomi adalah $300(60 \%)$ dari jumlah total nilai aspek manfaat.

\section{a) Pendapatan}

Pendapatan petani mitra dalam usahatani mangga mengalami peningkatan dan ada beberapa petani yang tidak mempunyai pengaruh terhadap pendapatan. Faktor cuaca dan perubahan iklim menjadi faktor yang harus diperhitungan sebagai faktor risiko yang berpengaruh signifikan terhadap pendapatan petani (Rochdiani dkk., 2017). Namun demikian dalam kemitraan ini, faktor yang mempengaruhi pendapatan seperti cuaca, hama penyakit dan luas lahan yang dimiliki petani mitra masih dirasa di luar kendali hubungan kemitraan. Bahkan, petani merasakan pendapatannya meningkat dengan adanya hubungan kemitraan yang dijalankan karena membuahkan pengetahuan baru, jaminan harga dan adanya kemudahan akses pasar. Berdasarkan hasil 
wawancara bahwa 37 petani (95\%), bahwa pendapatan petani meningkat setelah bergabung dengan kemitraan.

b) Harga/Jaminan Pasar

Harga mangga termasuk ke dalam harga yang tidak berfluktuatif. Berdasarkan hasil penelitian, petani mitra sebanyak 38 orang (97\%) menyatakan bahwa harga yang ditetapkan oleh perusahaan sama dengan harga pasar. Sedangkan 1 orang petani mitra $(3 \%)$, menyatakan bahwa harga lebih rendah dari harga pasar. UD Wulan Jaya tidak menetapkan harga yang lebih rendah dari pasar sehingga petani tidak merasa dirugikan. Perusahaan menetapkan harga yang tidak merugikan petani dengan tidak menetapkan harga di bawah pasar. Oleh karena itu, perusahaan selalu menetapkan harga yg relatif stabil untuk petani bahkan lebih tinggi dari pasar.

c) Produktivitas

Dalam ilmu ekonomi secara umum, produktivitas didefinisikan sebagai output dibagi input. Dengan kata lain produktivitas akan meningkat apabila dengan input yang sama dapat diperoleh hasil produksi yang lebih tinggi atau sebaliknya dengan tingkat hasil yang sama tetapi membutuhkan input yang lebih rendah. Peningkatan produktfitas sangat diharapkan oleh semua pihak yang bermitra. Karena dengan meningkatnya produktivitas mangga, maka pendapatan pun akan meningkat.

Berdasarkan hasil penelitian, sebanyak 39 petani mitra (100\%) menyatakan bahwa adanya kemitraan menghasilkan produktivitas yang lebih tinggi dibandingkan dengan tidak bergabung mitra. Program kemitraan ini bisa dikatakan berdampak positif terhadap perilaku petani dalam budidaya komoditas mangga. Meskipun memang tidak semua petani mengikuti saran dari perusahaan ataupun koordinator karena petani sudah banyak pengalaman di lahan. Namun, perusahaan tetap menghimbau kepada petani agar menggunakan bibit yang berkualitas, menggunakan input yang efisien dan tetap mempertahankan kualitas dalam penggunaannya. Himbauan disampaikan kepada koordinator untuk selanjutnya disampaikan kepada petani.

\section{d) Risiko Usaha}

Berdasarkan hasil penelitian, bahwa 39 petani mitra $(100 \%)$ menyatakan bahwa ketika ada risiko dalam usahatani mangga, maka risiko ditanggung oleh petani mitra. Contoh risiko yang terjadi seperti risiko produksi atau risko harga. Risiko produksi terjadi karena variasi hasil akibat berbagai faktor yang sulit diduga seperti cuaca, penyakit, hama dan variasi genetik. Hal tersebut berdampak kepada variasi hasil produksi mangga secara kualitas dan kuantitas (Rasmikayati dkk., 2017).

Risiko harga biasanya dikaitkan dengan keragaman dan ketidaktentuan harga yang diterima petani dan yang harus dibayarkan untuk input produksi. Jenis keragaman harga yang dapat diduga antara lain adalah trend harga, siklus harga, dan variasi harga berdasarkan musim. Tingkat harga yang berubah dapat berpengaruh pada pendapatan yang diperoleh. Oleh karena itu, risiko usaha di tanggung oleh petani mitra.

\section{2) Manfaat Teknis}

Aspek manfaat dari indikator teknis, faktor yang dinilai meliputi mutu dan penggunaan teknologi.

a) Mutu

Untuk menjaga mutu produksi mangga maka proses sortasi dan grading menjadi sangat penting (Azizah, 2018). Perusahaan menetapkan standar kualitas mangga dari mulai kualitas bibit hingga kegiatan sortasi dan grading. Menurut responden petani mitra sebanyak 37 
orang $(95 \%)$ menyebutkan bahwa adanya kemitraan memberikan dampak yang lebih baik dalam peningkatan mutu buah mangga. Sedangkan 2 orang petani mitra (5\%) menyatakan bahwa mutu mangga yang diproduksi petani setelah menjalin kemitraan sama saja dibandingkan dengan sebelum kemitraan. Hasil penelitian disimpulkan, bahwa mayoritas petani mitra merasakan manfaat positif dalam memperoleh mutu atau kualitas mangga. Hal tersebut karena perusahaan terbuka untuk memberikan informasi jika ada masalah di lapang dan tetap mengontrol kegiatan di lapang dengan tujuan menjaga kualitas mangga yang dihasilkan.

\section{b) Penguasaan Teknologi}

Berdasarkan hasil penelitian bahwa sebanyak 37 petani mitra (95\%) menyatakan bahwa pengetahuan dan keterampilan kelompok mitra mengenai penanganan komoditi yang dimitrakan sama saja dengan sebelum program kemitraan. Hal tersebut karena petani sudah lebih dahulu tahu terkait penguasaan teknologi yang digunakan seperti jenis pupuk dan obat-obatan apa yang perlu diberikan. Pengetahuan petani mengenai obat-obatan ini sangat penting dalam usahtani (Deviani dkk., 2019). Selain dari pupuk dan obat-obatan, adapun alat bantu dalam melakukan pemeliharaan mangga terhadap hama yaitu semprotan. Menurut Sulistyowati et al. (2015), respons petani mangga di Indonesia dalam mengadopsi teknologi baru masih sangat rendah. Senada dengan itu, mayoritas petani mitra mengetahui penguasaan teknologi yang digunakan secara turun temurun dari orang tuanya, dan apabila ada pembaharuan terkait teknologi baru, petani membandingkan produk yang digunakan dan saling bertukar informasi satu sama lain dengan petani lainnya untuk meminimalisir jumlah percobaan untuk perbandingan hasil produk yang digunakan.

\section{3) Manfaat Sosial}

Aspek manfaat dilihat dari indikator sosial meliputi kontinuitas kerjasama dan pelestarian lingkungan. Aspek ini mempunyai nilai total 100 .

a) Kontinuitas Kerjasama

Mengenai kontinuitas kerjasama, bahwa petani mitra sebanyak 39 orang $(100 \%)$ menginginkan adanya keberlanjutan kerjasama yang menguntungkan dalam pemasokan mangga. Keadaan kemitraan saat ini dirasa cukup menguntungkan baik untuk pihak petani maupun perusahaan terlepas dari kendala-kendala yang muncul selama pelaksanaannya.

Perusahaan pun sangat mengingkan kerjasama berkelanjutan supaya terjadinya kontinuitas suplai dari petani yang berdampak kepada operasional perusahaan. Peran koordinator diharapkan tetap membantu perusahaan dalam mengatasi petani di lapangan maupun dalam memasarkan mangga. Adanya sedikit bantuan dari koordinator tidak hanya digunakan untuk keberlangsungan usahatani mangga saja, melainkan untuk memenuhi kebutuhan rumah tangga petani.

b) Pelestarian Lingkungan

Berdasarkan hasil penelitian petani responden sebanyak 39 orang (100\%) menyatakan bahwa tidak adanya penanganan konservasi dan penanganan limbah dalam hubungan kemitraan. Walaupun begitu, petani secara independen memanfaatkan sisa dari hasil panen.

Konservasi tanah dari segi penempatan dan cara penggunaan sesuai kemampuan tanah dilakukan secara tepat guna oleh petani mitra. Begitupun untuk penggunaan air sebaik-baiknya dalam hal konservasi air 


\section{KESIMPULAN}

Berdasarkan hasil pembahasan dari penelitian yang telah dilakukan kesimpulan yang dapat diambil adalah bahwa pola kemitraan yang diterapkan oleh UD Wulan Jaya dengan petani mitra adalah pola kerjasama operasional agribisnis (KOA) di mana petani menyediakan lahan, tenaga kerja, bahan baku (pupuk dan obat-obatan) dan permodalan sendiri, sedangkan perusahaan menjamin produk dengan melakukan sortasi dan grading juga pemilihan pasar tetap dengan harga jual yang menguntunkan baik untuk petani maupun.

Sementara itu, nilai derajat kemitraan adalah sebesar 721 yang menyatakan bahwa kemitraan berada pada tingkat Madya (cukup baik). Nilai tersebut terdiri dari nilai aspek proses manajemen kemitraan sebesar 375 dan nilai aspek manfaat sebesar 346.

\section{DAFTAR PUSTAKA}

Amridha, Y., Heryanto, M. A., Saefudin, B. R., \& Awaliyah, F. (2020). The Analysis of The Employee's Job Satisfaction and Performance In Private Agricultural Company. Mahatani: Jurnal Agribisnis (Agribusiness and Agricultural Economics Journal), 2(2).

Anugrah, I. S. 2009. Mendudukkan Komoditas Mangga Sebagai Unggulan Daerah dalam Suatu Kebijakan Sistem Agribisnis: Upaya Menyatukan Dukungan Kelembagaan Bagi Eksistensi Petani. Analisis Kebijakan Pertanian. Volume 7 No. 2, Juni 2009: 189-211
Atlas, W. (2018). World Atlas. Retrieved April, 6, 2018.

Azizah, M. N., Rasmikayati, E., \& Saefudin, B. R. (2019). Perilaku Budidaya Petani Mangga Dikaitkan dengan Lembaga Pemasarannya di Kecamatan Greged Kabupaten Cirebon. Jurnal Ilmiah Mahasiswa Agroinfo Galuh, 5(1), 987-998.DOI: http://dx.doi.org/10.25157/jimag.v $5 \mathrm{i} 1.1447$.

Creswell, J. W. 2009. Quantitative methods. Research design: Qualitative, quantitative and mixed methods approaches, 145-171.

Darwis, V., Hastuti, E. L., \& Friyatno, S. 2016. Revitalisasi Kelembagaan Kemitraan Usaha dalam Pembangunan Agribisnis Hortikultura di Provinsi Sumatera Utara.

Deviani, F., Rochdiani, D., \& Saefudin, B. R. (2019). Analisis FaktorFaktor yang Mempengaruhi Produksi Usahatani Buncis Di Gabungan Kelompok Tani Lembang Agri Kabupaten Bandung Barat. Agrisocionomics: Jurnal Sosial Ekonomi Pertanian, 3(2), 165-173.

Ditjen Hortikultura. 2018. Peluang Ekspor Mangga Indonesia Menjanjikan. Diakses Melalui http://hortikultura.pertanian.go.id/? $\mathrm{p}=2884$

Eaton, C., \& Shepherd, A. 2001. Contract farming: Partnerships for Growth (No. 145). Food \& Agriculture Org.

Etzioni, A. 1985. Opening the preferences: A socio-economic research agenda. Journal of Behavioral Economics, 14(1), 183198. 
Pertanian, B. A. D. 1998. Kemitraan: Kebijaksanaan dan Penjelasan Pola Kemitraan Usaha Pertanian. Deptan. Jakarta.

Rasmikayati, E., Mukti, G. W., \& Saefudin, B. R. (2019, October). The Determinant Factors of The Dynamics of Agribusiness Behavior of the Mango Farmers in Greged Sub District, Cirebon District. In IOP Conference Series: Earth and Environmental Science (Vol. 334, No. 1, p. 012054). IOP Publishing. DOI: https://dx.doi.org/10.1088/17551315/334/1/012054.

Rasmikayati, E., \& Saefudin, B. R. (2018). Analisis Faktor-Faktor Yang Mampu Mendorong Petani Mangga Untuk Meningkatkan Perilaku Agribisnisnya Pada Era Globalisasi. Paradigma Agribisnis, l(1).

Rasmikayati, E., Sulistyowati, L., \& Saefudin, B. R. (2017). Risiko Produksi dan Pemasaran Terhadap Pendapatan Petani Mangga: Kelompok Mana yang Paling Berisiko. Mimbar Agribisnis: Jurnal Pemikiran Masyarakat Ilmiah Berwawasan Agribisnis, 3(2), $\quad$ 105-116. DOI: http://dx.doi.org/10.25157/ma.v3i2 .564 .

Rachmah, A. D., Rasmikayati, E., \& Saefudin, B. R. (2019). Factors Related to Continuation of Mango Cultivation. Jurnal Pertanian, 10(2), 52-60. DOI: http://dx.doi.org/10.30997/jp.v10i2 .1864 .

Rochdiani, D., Kuswarini, K., \& Bobby, R. S. (2017). Risiko Perubahan Iklim Serta Pengaruhnya Terhadap Pendapatan Petani Usahatani Padi di Jawa Barat. In Prosiding
Seminar Nasional Mitigasi dan Strategi Adaptasi Dampak Perubahan Iklim di Indonesia. Pekanbaru (ID): Universitas Islam Riau.

Saptana, S., Indraningsih, K. S. 2006. Mewujudkan Keunggulan Kompetitif melalui Pengembangan Kemitraan Usaha Hortikultura. Forum Penelitian Agro Ekonomi. Vol, 24(1), 61-76.

Saptana, S., Indraningsih, K. S., \& Hastuti, E. L. (2007). Analisis Kelembagaan Kemitraan Usaha di Sentra Sentra Produksi Sayuran (suatu Kajian Atas Kasus Kelembagaan Kemitraan USAha di Bali, Sumatera Utara, dan Jawa Barat). SOCA: Jurnal Sosial Ekonomi Pertanian, 7(3), 44050.

Sari, A. F., Rasmikayati, E., \& Saefudin, B. R. (2019). Behavioral Dynamics of Farmers and First Buyer in Marketing Mangoes in Sedong District, Cirebon Regency, West Java. AGRIFOR, 18(1), 63-72. DOI: https://doi.org/10.31293/af.v18i1.4 072

Sulistyowati, L., Natawidjaja, R. S., \& Rahmat, B. (2015). Adoption of Technology and Economics Efficiency of The Small-holder Mango Farmers in Indonesia. International Journal of Applied Business and Economic Research (Ijaber), 13(7), 4621-4645. ISSN: 0972-7302. Serial Publication PVT. LTD. New Delhi. India. 